DOI: http://dx.doi.org/10.24093/awejtls/vol1no3.5

\title{
A Pragma-stylistic Study of Hybrid Speech Acts in Selected Dramatic Texts
}

\author{
Riyadh Khalil Ibrahim \\ Department of English, College of Languages \\ University of Baghda, Iraq (Corresponding Author) \\ Khamail Ali Waheeb \\ Wasit Directorate of Education, Iraq
}

\begin{abstract}
The study is intended to investigate the role of speech act theory (SAT) in understanding dramatic texts through using pragma-stylistic approach. It is also an attempt to examine the stylistic effects of using speech acts (SAs) and their implication in conveying the theme of the play and the intentions of the characters. Therefore, eight extracts are selected from Harold Pinter's Plays : A Night Out and The Birthday party, to be the data of analysis. The analysis reveals that the interaction between stylistics and pragmatics is a vital tool for analyzing dramatic texts in terms of (SAT). SAs are grouped into systematic combination depending on the purpose of the speaker or the playwright. Direct of fit is the most decisive aspect of the combination of some hybrid speech acts. The pragma-stylistics analysis of hybrid (SAs) also reveals the importance of these speech acts in conveying the intended message of the dramatist through the contextual details offered about the characters and events. These details can secure a proper interpretation of the socio-psychological relationships between the characters and the audience of the play.

Keywords: Hybrid speech acts, felicity conditions, pragma-stylistics

Cite as: Ibrahim, R.K., \& Waheeb, K. A. (2017). A Pragma-stylistic Study of Hybrid Speech Acts in Selected Dramatic Texts. Arab World English Journal for Translation \& Literary Studies, 1(2). DOI: http://dx.doi.org/10.24093/awejtls/vol1no3.5
\end{abstract}

